\title{
Trefjagollurshús - sjúkratilfelli með umræðu
}

\section{Jón Porkell Einarsson ${ }^{1}$}

deildarlæknir

Ragnar

Danielsen ${ }^{2}$

hjartalæknir

\section{Ólafur Skúli}

Indriðason ${ }^{1}$

nýrnalæknir

\section{Tómas}

Guðbjartsson, 4

hjarta- og lungnaskurðlæknir

Lykilorð: trefjagollurshús, hjartabilun, bjúgur, hjartaómun, hjartapræðing, skurðaðgerð.

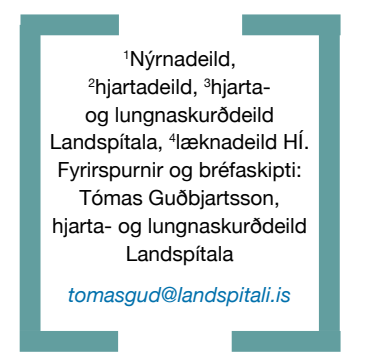
Ágrip

Trefjagollurshús er sjaldgæft fyrirbæri par sem gollurshúsið prengir að hjartanu og hindrar eðlilega fyllingu pess. Afleiðingin er vinstri og hægri hjartabilun með próttleysi, mæði og bjúg á útlimum. Trefjagollurshús er oftast af ópekktum orsökum, en getur komið í kjölfar sýkinga, geislameðferðar, bandvefssjúkdóma og asbestmengunar. Greining getur verið flókin og tefst oft. Meðferð er yfirleitt skurðaðgerð par sem hluti gollurshúsins er fjarlægður. Hér er lýst tilfelli af Landspítala.

\section{Sjúkratilfelli}

Tæplega sextugur maður leitaði á bráđamóttöku Landspítala vegna preytu og vaxandi bjúgs á ganglimum. Hann hafði á tæpum mánuði pyngst um $30 \mathrm{~kg}$, prátt fyrir töku pvagræsilyfja. Af pessum sökum átti hann erfitt með gang en kvaðst hvorki finna fyrir aukinni mæði né kviðverkjum.

Á átta árum hafði hann verið lagður nokkrum sinnum inn á sjúkrahús vegna svipaðra einkenna. Pvagrannsóknir höfðu útilokað nýrungaheilkenni (nephrotic syndrome) og rannsóknir á lifrarstarfsemi og útlimabláæðum voru eðlilegar. Í einni af fyrstu innlögnunum (júní 2001) var gerð hjartaómun par sem grunur vaknaði um trefjagollurshús. Mælt var með frekari rannsóknum, en par sem sjúklingur dvaldi langdvölum erlendis misfórst eftirlit. Við áðurnefndar innlagnir var hann jafnan meðhöndlaður með lykkju-pvagræsilyfjum (fúrósemíð) í æð, en skipt yfir í töflur pegar bjúgur minnkaði. Yfirleitt löguðust einkenni á nokkrum vikum og hann náði aftur fyrri pyngd (um 130 $\mathrm{kg}$ ). Viðhaldsskammtur fúrósemíðs var að jafnaði í kringum 80-120 mg daglega. Við væg versnandi einkenni leitaði hann ekki læknis, heldur jók sjálfur skammt pvagræsilyfja og forðaðist áreynslu í nokkra daga. Smám saman fóru einkenni pó versnandi, mæði varð meira áberandi auk preytu við áreynslu og bjúgsöfnun á útlimum.

Í heilsufarssögu kom fram að hann hafði um nokkurra ára skeið haft vægan háprýsting og sykursýki af gerð 2, auk pess að hafa reykt (30 pakkaár). Fimmtán árum áður hafði hann verið rannsakaður vegna vaxandi mæði. Voru meðal annars reynd berkjuvíkkandi lyf án árangurs. Á röntgenmynd af lungum sáust pykknanir á fleiðru og var í fyrstu ákveðið að fylgjast með peim. Um mitt ár 2001 var gerð opin sýnataka á fleiðru en einnig miðmætisspeglun vegna stækkaðra miðmætiseitla. Vefjagreining sýndi eðlilega eitla og ósérhæfða bólgu í fleiðru. Engin merki sáust um illkynja vöxt. Voru bólgubreytingarnar taldar geta skýrst af asbestmengun sem hann hafði áður orðið fyrir við vinnu sína sem pípulagningamaður. Ári frá sýnatökunni (2002) hætti hann að vinna og voru dæmdar örorkubætur.

Við skoðun á bráđamóttöku vó hann 160 kg og mældist tveir metrar á hæð. Blóðprýstingur var 130/80 mmHg og púls 70 slög á mínútu, greinilega veikari við inn- en útöndun. Bláæðar á hálsi voru pandar og breyttust ekki við innöndun. Við hjartahlustun heyrðist priðja hjartahljóð í hlébili og hátíðnióhljóð í slagbili við innöndun yfir 3.-4. rifjabili vinstra megin. Væg brakhljóð heyrðust yfir lungum neðarlega. Kviður var paninn með skiptideyfu og lifur stækkuð við preifingu. Á neðri hluta líkama var mikill bjúgur sem náði allt frá tám og upp að mitti.

Blóðrannsóknir við komu sýndu eðlilegan blóðhag, sökk, blóðsölt, kreatínín, lifrarpróf, og skjaldkirtilspróf, en NT-proBNP (N-terminal prohormone brain natriuretic peptide) mældist vægt hækkað. Strimilpróf og smásjárskoðun á pvagi voru ómarkverð (tafla I). Hjartalínurit sýndi óreglulegan takt með aukaslögum frá gáttum og

Tafla I. Niðurstöður helstu rannsókna við komu á bráðamóttöku. Viðmiðunarmörk eru gefin upp í sviga.

\begin{tabular}{lll}
\hline Hemóglóbín & $143 \mathrm{~g} / \mathrm{L}$ & $(134-171)$ \\
\hline Natríum & $135 \mathrm{mmol} / \mathrm{L}$ & $(137-145)$ \\
\hline Kalíum & $3,4 \mathrm{mmol} / \mathrm{L}$ & $(3,5-5,0)$ \\
\hline Klór & $102 \mathrm{mmol} / \mathrm{L}$ & $(98-110)$ \\
\hline Kreatínín & $82 \mu \mathrm{mol} / \mathrm{L}$ & $(60-100)$ \\
\hline CRP & $6 \mathrm{mg} / \mathrm{L}$ & $(<3)$ \\
\hline Albúmín & $25 \mathrm{~g} / \mathrm{L}$ & $(36-45)$ \\
\hline NT-pro-BNP & $347 \mathrm{ng} / \mathrm{L}$ & $(<230)$ \\
\hline ALP & $39 \mathrm{U} / \mathrm{L}$ & $(35-105)$ \\
\hline ALAT & $26 \mathrm{U} / \mathrm{L}$ & $(<70)$ \\
\hline TSH & $4,63 \mathrm{mU} / \mathrm{L}$ & $(0,3-4,20)$ \\
\hline Pvag strimilpróf & Eðlilegt & \\
\hline
\end{tabular}


Mynd 1. Prýstingsmæling við hægri og vinstri hjartapræðingu. Kvađratrótarteikn (ör) sést greinilega í panbili. Stærri topparnir eru útslag vinstra slegils og pær minni sýna útslag frá hægra slegli.

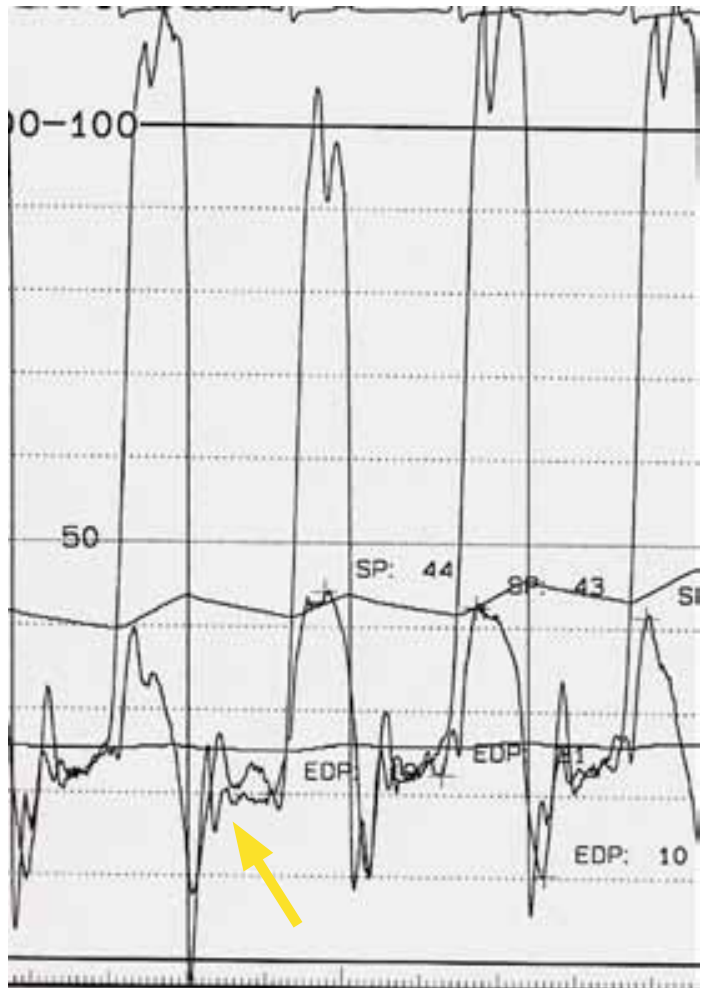

lítil QRS-útslög. Á lungnamynd sáust kalkanir í báðum fleiðrum og stasabreytingar í lungum.

Sjúklingur var lagður inn og meðhöndlaður með $80 \mathrm{mg}$ af fúrósemíði prisvar á dag í æð. Ómskoðun af hjarta sýndi óeðlilegan samdrátt á vinstri slegli, útstreymisbrot í kringum $40 \%$ og óeðlilega fyllingu í hlébili. Par sem gollurshúsið virtist prengja að hjartanu vaknaði sterkur grunur um trefjagollurshús. Pví var ákveðið að gera bæði hægri og vinstri hjartapræðingu. Mældist prýstingur 1 aðalstofni lungnaslagæðar 26/17

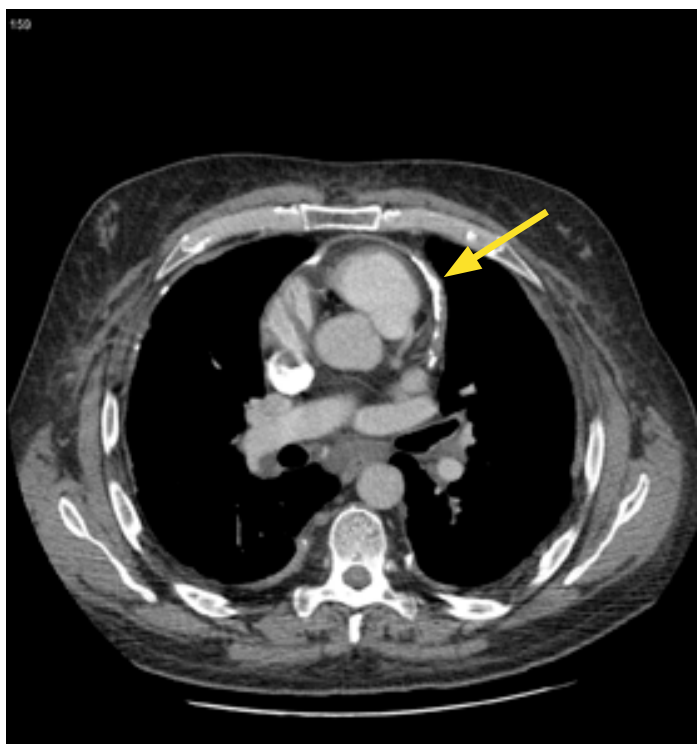

Mynd 2. Tölvusneiðmyndir af brjóstholi sem sýna kalkanir í gollurshúsi (ör) og fleiðruholi.
$\mathrm{mmHg}$, meðalprýstingur $21 \mathrm{mmHg}$ og meðal fleygprýstingur $19 \mathrm{mmHg}$. Meðalprýstingur í hægri gátt var $20 \mathrm{mmHg}$. Pegar mældar voru prýstingskúrfur í hlébili, samtímis í hægri og vinstri slegli, sást svokallað kvaðratrótarteikn (square root sign, mynd 1). Auk pess mældist prýstingur í enda hlébils sá sami í báđum sleglum, eða $22 \mathrm{mmHg}$. Kransæðar voru eðlilegar.

Eftir hjartapræðinguna voru fengnar tölvusneiðmyndir af brjóst- og kviðarholi og segulómun af brjóstholi (mynd 2 og 3). Pær sýndu greinilega pykknað og kalkað gollurshús, sérstaklega við brodd hjartans par sem pykkt gollurshússins mældist 4-5 mm (mynd 2 og 3). Einnig sáust kalkanir í fleiðru. Hjartastærð var innan eðlilegra marka en lifur og milta greinilega stækkuð.

Sjúklingur svaraði vel meðferð á fyrstu dögum eftir innlögn, einkum eftir að hýdróklórtíasíði var bætt við fúrósemíð meðferðina. Á 25 dögum hafði hann náð aftur sömu pyngd og áður (130 kg) (mynd 4a). Við útskrift var hann á $160 \mathrm{mg}$ af fúrósemíði prisvar á dag auk sykursýkislyfs og kalíumuppbótar.

Ákveðið var að gera skurðgerð og að ósk sjúklings var hún ráðgerð hálfu ári síðar. Fyrir aðgerð vó hann $135 \mathrm{~kg}$. Hann tók pá fúrósemíð 200 mg prisvar á dag og hýdróklórtíazíð 25 $\mathrm{mg}$ daglega. Engu að síður var greinilegur bjúgur á ganglimum og vægar stasabreytingar á lungnamynd. Í aðgerðinni, sem var gerð í gegnum bringubeinsskurð, var fremri hluti gollurshússins fjarlægður aftur að pindartaug (n. phrenicus) beggja vegna. Gollurshúsið reyndist mjög pykkt og víða kalkað eins og bein (mynd 5). Purfti að skræla pað af hjartanu enda vaxið fast við yfirborð

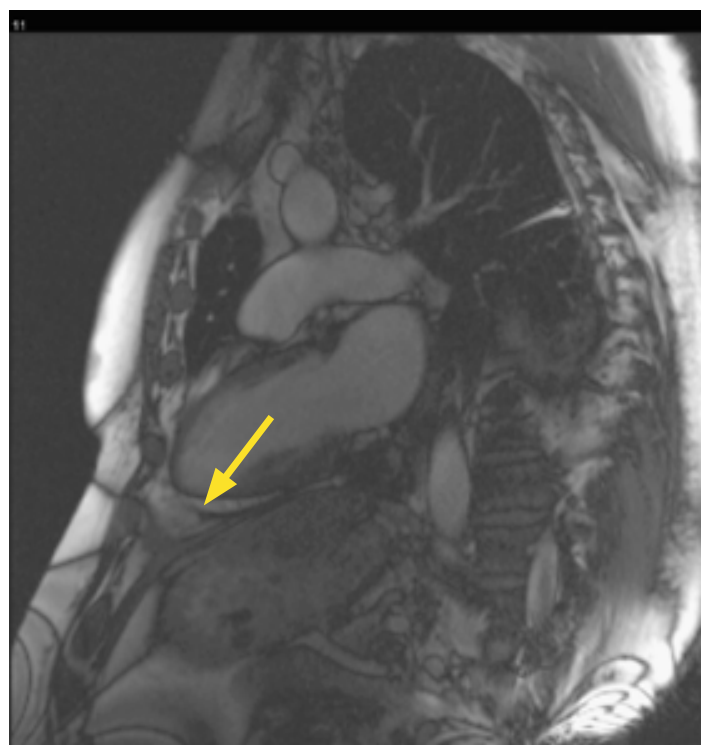

Mynd 3. Segulómun af brjóstholi sem sýnir pykkt gollurshús. 
pess. Aðgerðin gekk vel og var blæðing $550 \mathrm{ml}$. Eftir aðgerðina var hann sólarhring á gjörgæslu og purfti hvorki öndunarvél né æðahvetjandi lyf. Gefin voru pvagræsilyf eftir aðgerðina, fyrst í æð en síðan í töfluformi. Smásjárskoðun á gollurshúsi sýndi aðeins ósértæka bólgu og kalkanir. Hann útskrifaðist sex dögum eftir aðgerð og vó pá $135 \mathrm{~kg}$ eins og við innlögn. Hjartaómun sýndi pokkalegan samdrátt á vinstri slegli (útstreymisbrot 45\%) og dopplerhraði yfir míturloku og vefjadoppler bentu til pess að fylliprýstingur í vinstri slegli væri undir $20 \mathrm{mmHg}$. Hann var útskrifaður á fúrósemíði, $40 \mathrm{mg}$ tvisvar á dag. Viku eftir útskrift var hýdróklórtíazíði bætt við, $25 \mathrm{mg}$ daglega, par sem hann hafði pyngst um prjú kg. Hjartaómun tveimur vikum eftir útskrift sýndi næstum eðlilegt hreyfimynstur á vinstri slegli og vægt skert útstreymisbrot (50\%). Á næstu vikum minnkaði bjúgur á ganglimum enn frekar og mæði sömuleiðis. Sex vikum eftir aðgerð var hann $129 \mathrm{~kg}$, og aðeins vottur af bjúg á ganglimum. Mánuði frá aðgerð greindist hann með gáttatif. Var pví gerð rafvending tveimur mánuðum síðar sem tókst vel. Rúmu ári frá aðgerð lét hann vel af sér. Hjartsláttur var reglulegur, mæði mun minni og bjúgur á ganglimum horfinn (mynd $4 b$ ). Auk pess hafði pvagræsilyfjameðferð verið minnkuð í $25 \mathrm{mg}$ af hýdróklórtíasíði og $40 \mathrm{mg}$ fúrósemíði daglega.

\section{Umræơa og yfirlit um sjúkdóminn}

Orsakir

Trefjagollurshús er sjaldgæfur sjúkdómur og hefur að pví höfundar best vita ekki verið lýst áđur í Læknablaðinu. Okkur er pó kunnugt um tilfelli sem greind hafa verið áður á Landspítala. Nýgengi trefjagollurshúss er breytilegt eftir heimsálfum og ræðst af algengi orsakavaldandi sjúkdóma. Faraldsfræðilegar rannsóknir eru af skornum skammti. Ein sú stærsta er frá Indlandi og tekur til 359 sjúklinga. ${ }^{1}$ Í peirri rannsókn og öðrum sambærilegum er aðeins litið á sjúk- linga sem gengust undir skurðaðgerð. ${ }^{1-3}$ Orsakir trefjagollurshúss eru fjölmargar og eru pær helstu sýndar í töflu II. Í priðja heiminum eru berklar algengastir, en á Vesturlöndum er orsök oftast ópekkt eða rakin til gollurshússbólgu af völdum

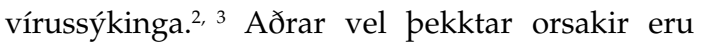
samvextir eftir brjóstholsskurðaðgerðir, geislameðferð á brjósthol, asbestmengun, illkynja sjúkdómar og bandvefssjúkdómar, svo sem iktsýki og rauðir úlfar. ${ }^{2,4}$

\section{Einkenni og teikn}

Bæði Forn-Egyptar og Grikkir lýstu einkennum trefjagollurshúss. ${ }^{5}$ Einnig eru til nákvæmar lýsingar á sjúkdómnum frá miðöldum. Pannig lýsti Richard Lower sjúklingi með mæði og slitróttan púls (intermittent) pegar árið 1669.6, ${ }^{7}$ Rúmum 200 árum síðar lýsti Adolf Kussmaul fyrstur veikluðum slagæðapúlsi við innöndun. Fyrirbærið kallaði hann pulsus paradoxus. ${ }^{8}$ Einnig er kennt við hann svokallað Kussmaulsteikn (Kussmaul's sign), en pað eru pandar bláæðar á hálsi sem penjast meira út við innöndun, og geta sést við trefjagollurshús. Löngu síðar, eða 1935, var lýst fyrstu árangursríku skurðaðgerðinni við trefjagollurshúsi. ${ }^{9}$ Sjúklingar með alvarlegt trefjagollurshús eru flestir með bjúg, oftast á neðri hluta líkamans og pá sérstaklega ganglimum eins og sást í pessu tilfelli. ${ }^{3,10}$ Einnig getur sést dreifður bjúgur, meðal annars á höndum og í andliti, og kallast holdbjúgur (anasarka). Preyta og áreynslumæði eru mjög algengar kvartanir, líkt og kvið- og brjóstverkir og gáttatif. ${ }^{3}$ Í okkar tilfelli var 15 ára saga um óútskýrða mæði auk átta ára sögu um bjúg á ganglimum og preytu við áreynslu. Allt eru petta einkenni sem hægt er að rekja til trefjagollurshúss. Pví er ljóst að veruleg töf varð á greiningu.

Við skoðun er dæmigert að sjá pandar bláæðar á hálsi og bjúg á ganglimum. Lifur er oft stækkuð og teikn um vökva í kvið (skiptideyfa) og fleiðru (minnkuð öndunarhljóð, bankdeyfa). ${ }^{3}$ Pessi teikn geta flest sést við aðra sjúkdóma og

Tafla II. Orsakir trefjagollurshúss í premur stórum erlendum rannsóknum. Gefinn er upp fjöldi sjúklinga og \% í sviga.

\begin{tabular}{|c|c|c|c|}
\hline & $\begin{array}{l}\text { Ling og fél. (3) } \\
135 \text { sjúklingar greindir á Mayo } \\
\text { Clinic, 1985-1995 }\end{array}$ & $\begin{array}{c}\text { Bertog og fél. (2) } \\
163 \text { sjúklingar greindir á Cleveland } \\
\text { Clinic, 1997-2000 }\end{array}$ & $\begin{array}{l}\text { Chowdhury og fél. (1) } \\
395 \text { sjúklingar greindir í Nýju- } \\
\text { Delí 1984-2004 }\end{array}$ \\
\hline Ópekkt / vírussýking & $45(33)$ & $75(46)$ & $31(8)$ \\
\hline Samvextir í kjölfar hjartaaðgerðar & $24(18)$ & $60(37)$ & $9(2)$ \\
\hline Geislameðferð á brjósthol & $17(13)$ & $15(9)$ & - \\
\hline Bandvefssjúkdómar & $10(7)$ & $5(3)$ & - \\
\hline Gollurshússbólga & $22(16)$ & $1(1)$ & - \\
\hline Tengt sýkingum (berklar, graftarsýking í gollurshúsi) & $4(3)$ & $6(4)$ & $351(89)$ \\
\hline Aðrar orsakir & $13(9)$ & $<1(<1)$ & $4(1)$ \\
\hline
\end{tabular}



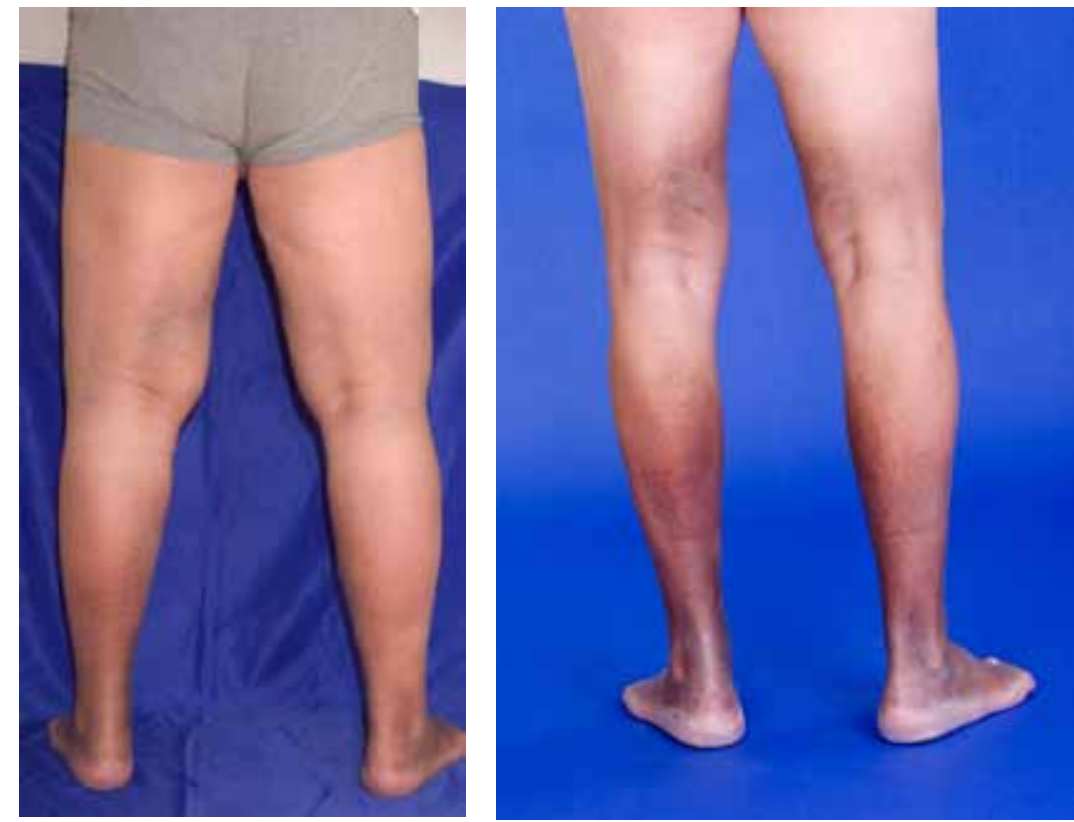

Mynd 4 a, b. (a) Mynd af neðri útlimum tekin í febrúar 2008, tæplega fiórum vikum eftir innlögn vegna mikls bjúgs á útlimum (sjá texta). Prátt fyrir kröftuga pvagræsilyfjameðferð er bjúgur enn til staðar, sérstaklega á fótleggium. Einnig sjást stasabreytingar á fótum.

(b) Mynd tekin ári eftir aðgerơ. Bjúgur er nánast horfinn af útlimum en stasabreytingar á húd enn áberandi á fótleggium.

mismunagreiningar eru pví margar. Má par nefna hjartabilun vegna hjartavöðvasjúkdóms eða lokuleka, hjartapröng (cardiac tamponade)

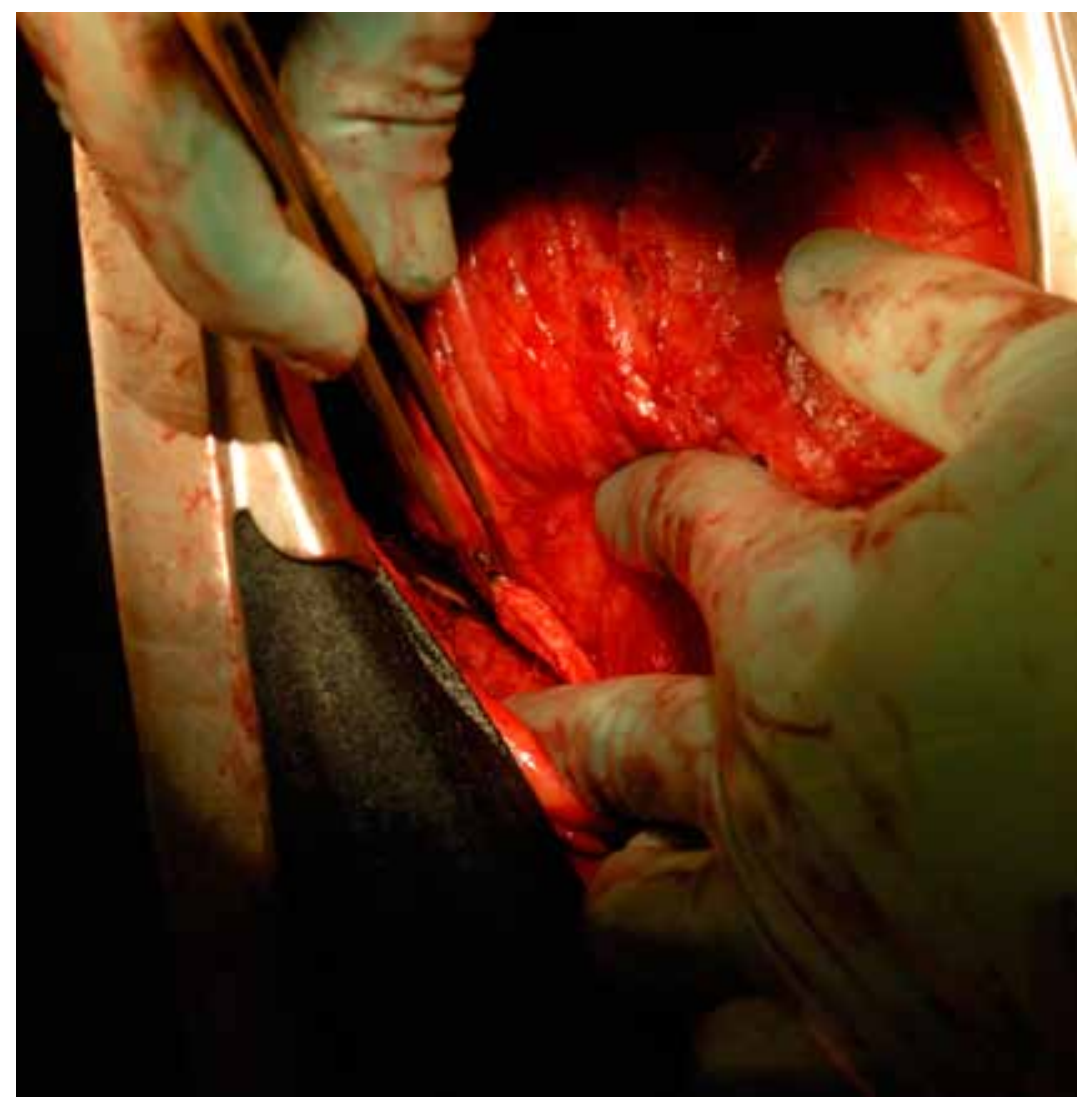

Mynd 5. Mynd úr aðgerð sem sýnir hart og pykknað gollurshús í tangarkjaftinum. Fyrir miðri mynd er hægri slegill hjartans. og prýstiloftbrjóst. $^{11}$ Hjá okkar sjúklingi var Kussmaulsteikn til staðar með pulsus paradoxus sem pó sést oftar hjá sjúklingum með hjartapröng en trefjagollurshús. ${ }^{3}$

\section{Lifeðlisfræði}

Gollurshús er punnur en sterkur sekkur, samsettur úr tveimur lögum; háluhjúp (pericardium visceralis) sem liggur pétt að yfirborði hjartans, og trefjasekk (pericardium parietalis) sem er utar. Undir eðlilegum kringumstæðum kemur gollurshúsið í veg fyrir núning við hreyfingar hjartans og getur gefið eftir í hlébili. Petta gerir báðum sleglum kleift að penjast út og fyllast. Við trefjagollurshús hindrar stíft gollurshúsið að sleglarnir geti panist út og að hjartað fyllist með eðlilegum hætti. Petta veldur pví að dæluvirkni hjartans skerðist., ${ }^{5,12,13}$

Við eðlilegar aðstæður minnkar innöndun prýsting í brjóstholi, lungnablóðrásinni og sleglum hjartans. Sá prýstingsmunur sem er á milli vinstri hluta hjartans og lungnabláæðanna breytir hins vegar ekki pví að prýstingurinn fellur jafnt á báðum stöðum. Hjá sjúklingi með trefjagollurshús verða engar öndunartengdar breytingar á prýstingi í sleglum, en pað sama á ekki við um lungnablóðrásina. Við innöndun lækkar pví prýstingur í lungnabláæðum en helst óbreyttur í vinstri slegli. раð veldur pví að minna rúmmál streymir um míturlokuna og yfir til vinstri slegils í hlébili. Par sem sleglarnir eru nú háðir hvor öðrum eykst að sama skapi rúmmál hægri slegils. Við petta flyst sleglaskilveggur meira til vinstri og flæðishraði í hlébili í lifrarbláæðum og yfir príblöðkulokuna eykst við innöndun. Við útöndun verður hins vegar aftur aukið innstreymi inn í vinstri slegil en minnkað til pess hægri. ${ }^{13,16}$

\section{Greining}

Á venjulegri röntgenmynd af brjóstholi sjást kalkanir í gollurshúsi hjá um priðjungi sjúklinga. Pessar kalkanir eru sterk vísbending um trefjagollurshús, svo fremi sem einkenni hægri hjartabilunar eru til staðar. ${ }^{3}$

Á tvívíddar hjartaómun sést oft pykknað gollurshús, óeðlileg hreyfing á sleglaskilvegg og bakveggur vinstri slegils er flatur í hlébili. Vinstri gátt er iðulega stækkuð, öndunartengdar breytingar á stærð slegla áberandi og neðri holæð (vena cava inferior) er panin. Með M-tækniómun er dæmigert að sjá merki um hindrun á innflæði í vinstri slegli í hlébili. Sést petta best sem brattur E-F halli á hreyfiómriti míturlokunnar. Einnig sést snemma í hlébili snögg fram- og afturhreyfing á sleglaskilvegg sem svarar til svokallaðs „pericardial knock“ á 
hjartahljóðriti. Petta getur samrýmst ýktum 3. hjartatóni vegna snöggrar hindrunar á fyllingu vinstri slegils. Auðvelt er að mæla pykkt á gollurshúsi aftan og neðan við hjartað. Hreyfing á bak- og hliðarvegg vinstri slegils í miðju hlébili er einnig áberandi lítil. Með sérstöku stafrænu mati (digitized M-mode echocardiography) er skýrar hægt að sýna fram á aukinn panhraða vinstri slegils (left ventricular peak diastolic dimension lengthening rate) snemma 1 hlébili. ${ }^{17}$ Með Doppler hjartaómun er hægt að greina merki um skerta fyllingu vinstri slegils í hlébili og truflun á eðlilegu samspili prýstings 1 hjartahólfum og innan brjósthols. ${ }^{13,16}$ Pykknað gollurshús dempar pau áhrif sem öndunartengdar innanbrjósthols prýstingsbreytingar hafa á prýsting í gollurshúsinu við eðlilegar aðstæður. Með Doppler kemur petta fram sem meira en 25\% minnkun á flæðishraða yfir míturloku í hlébili við innöndun. Flæðishraði í lifrarbláæðum og yfir príblöðkulokuna er hins vegar aukinn. Við útöndun snúast pessar breytingar við. Svipaðar breytingar sjást einnig ef mikill vökvi er í gollurshúsi (tamponade). Lífeðlisfræðin par að baki er pó nokkuð frábrugðin og aðrar upplýsingar sem einnig sjást á hjartaómun eru gagnlegar til aðgreiningar.13, ${ }^{16}$ Flókið getur verið að greina parna á milli pegar fara saman bólgubreytingar og pykknun á gollurshúsi ásamt vægri vökvasöfnun, lífeðlisfræðin getur pá verið blönduð.

Tölvusneiðmyndir og segulómun af hjarta eru mjög gagnlegar til að meta pykkt gollurshús. ${ }^{18}$ 19 Tölvusneiðmynd ætti í flestum tilfellum að duga. Eðlileg pykkt á gollurshúsi útilokar pó ekki trefjagollurshús. Pannig eru allt að 20\% sjúklinga sem fara í aðgerð vegna trefjagollurshús með eðlilega pykkt á gollurshúsi á pessum myndrannsóknum. Á hinn bóginn parf pykknað gollurshús ekki alltaf að pýða аð pað prengi að hjartanu. Gollurshúspykkt sem er yfir $6 \mathrm{~mm}$ eykur pó verulega líkur á pví að um trefjagollurshús sé að ræða.

Vinstri og hægri hjartapræðing gefur mikilvægar upplýsingar til greiningar á trefjagollurshúsi. ${ }^{20}$ Prjú atriði eru mikilvægust. Í fyrsta lagi hækkun og jöfnun á prýstingi í hlébili í öllum hjartahólfum. Í öðru lagi líkist útlit á prýstingskúrfum frá vinstri og hægri slegli snemma í hlébili kvaðratrótarteikni (einnig kallað “dipand-plateau") (mynd 1). Í priðja lagi er áberandi y-fallandi í prýstingskúrfu frá hægri gátt.

\section{Meðferð og horfur}

Helsta meðferð trefjagollurshúss er skurðaðgerð. Oftast er fremri hluti gollurshússins fjarlægður

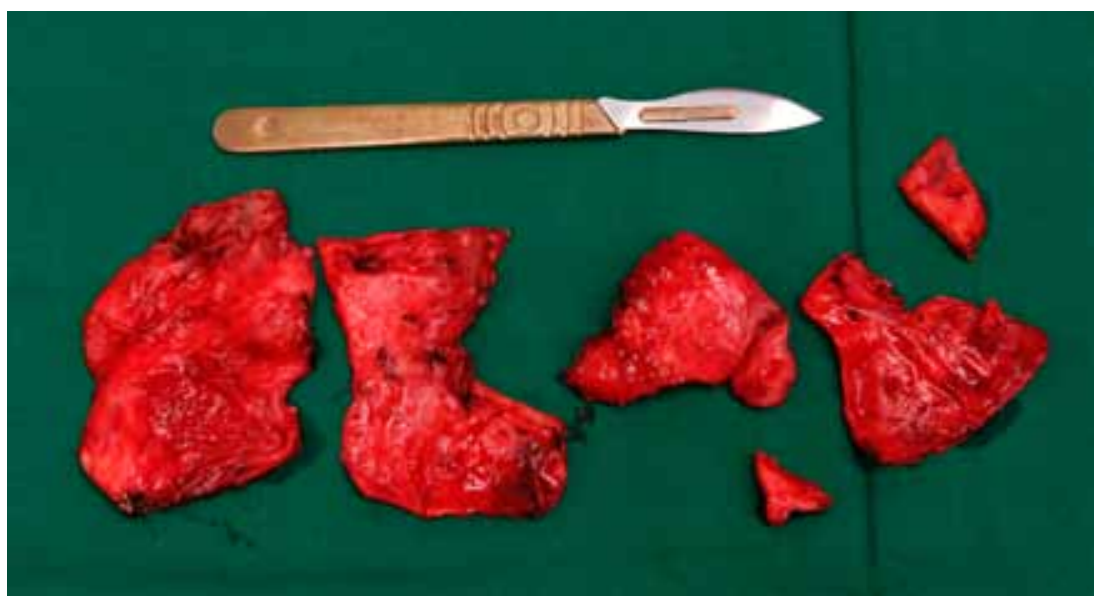

aftur að pindartaugum báðum megin.1, ${ }^{2}$ Skurðaðgerð reyndist vel í pessu tilfellli. Pegar fremri hluti gollurshússins hafði verið fjarlægður sást strax í sárinu hvernig fylling hjartans batnaði. Ómskoðun af hjarta fyrir og eftir aðgerðina staðfesti petta. Auk pess lagaðist mæði verulega og bjúgur á útlimum hvarf á nokkrum vikum. Um leið var hægt að minnka skammta af pvagræsilyfjum verulega. Fjöldi rannsókna hafa staðfest góðan árangur skurðaðgerðar. ${ }^{1-3,}$ 21-23 Engu að síður er um áhættusama aðgerð að ræða og á stærri hjartaskurðdeildum erlendis er dánartíðni á bilinu 6-8\%. ${ }^{2,3}$ Dánarorsök tengist oft hjartabilun en priðjungur sjúklinga hjartabilast alvarlega á fyrstu dögum eftir aðgerð. Ástæðan er rýrnun á hjartavöðva vegna langvarandi prengsla í gollurshúsinu. Samdráttargeta hjartans lagast oftast á nokkrum dögum ${ }^{1,24}$ en pó ekki alltaf., 15 Blæðingar eru annað vandamál við pessar aðgerðir, enda gollurshúsið iðulega fast við yfirborð hjartans. ${ }^{1}$ Hjá sjúklingum sem ekki er treyst í aðgerð er beitt pvagræsilyfjum. ${ }^{25}$ Slíkri meðferð er einnig beitt pegar einkenni eru væg og ekki talin ábending fyrir skurðaðgerð. Pvagræsilyf eru oft áhrifarík, að minnsta kosti í upphafi. Petta sást glöggt í okkar tilfelli en sjúklingurinn léttist um $30 \mathrm{~kg}$ á fjórum vikum. Áhrif pvagræsilyfja eru pó ekki viðvarandi og einkenni versna oft með tímanum. Í rannsókn Bertog og félaga var sýnt fram á hærri tíðni ótímabærs dauða ef skurðaðgerð var ekki gerð. ${ }^{2}$ Langtímahorfur eftir skurðaðgerð ráðast aðallega af alvarleika hjartabilunar og undirliggjandi orsök. ${ }^{2}$ Horfur eru verstar við trefjagollurshús eftir geislameðferð, en pá hefur hjartavöðvinn oft orðið fyrir geislaskemmdum. ${ }^{2}$

Petta tilfelli sýnir hversu erfitt getur verið að greina trefjagollurshús. Um leið undirstrikar tilfellið mikilvægi pess að greina orsakir hjartabilunar sem mögulega er hægt að lækna, til dæmis með skurðaðgerð eins og í pessu tilfelli.
Mynd 6. Bútar af gollurshúsi sem fjarlegt var við aðgerðina. Smásjárskoðun sýndi ósértæka bólgu og kalkanir. 


\section{Pakkir og leyfi}

Pakkir fá Anna Ellen Douglas ljósmyndari á Landspítala og Margrét Sturludóttir læknir fyrir hjálp við gerð myndefnis. Sjúklingurinn gaf skriflegt leyfi fyrir birtingu pessa tilfellis, bæði texta og mynda.

\section{Heimildir}

1. Chowdhury UK, Subramaniam GK, Kumar AS, et al Pericardiectomy for constrictive pericarditis: a clinical, echocardiographic, and hemodynamic evaluation of two surgical techniques. Ann Thorac Surg 2006; 81: 522-9.

2. Bertog SC, Thambidorai SK, Parakh K, et al. Constrictive pericarditis: etiology and cause-specific survival after pericardiectomy. J Am Coll Cardiol 2004; 43: 1445-52.

3. Ling LH, Oh JK, Schaff HV, et al. Constrictive pericarditis in the modern era: evolving clinical spectrum and impact on outcome after pericardiectomy. Circulation 1999; 100: 1380-6.

4. Kaul TK, Fields BL, Kahn DR. Primary malignant pericardia mesothelioma: a case report and review. J Cardiovasc Surg (Torino) 1994; 35: 261-7.

5. Osterberg L, Vagelos R, Atwood JE. Case presentation and review: constrictive pericarditis. West J Med 1998; 169: 232-9.

6. McCaughan BC, Schaff HV, Piehler JM, et al. Early and late results of pericardiectomy for constrictive pericarditis. J Thorac Cardiovasc Surg 1985; 89: 340-50.

7. Fowler NO. Constrictive pericarditis: its history and current status. Clin Cardiol 1995; 18: 341-50.

8. Bilchick KC, Wise RA. Paradoxical physical findings described by Kussmaul: pulsus paradoxus and Kussmaul's sign. Lancet 2002; 359: 1940-2.

9. White P. Chronic constrictive pericarditis (Pick's disease) treated by pericardial resection. Lancet 1935; 2: 597.

10. Imazio $M$, Trinchero $R$. Clinical management of acute pericardial disease: a review of results and outcomes. Ital Heart J 2004; 5: 803-17.

11. Khasnis A, Lokhandwala Y. Clinical signs in medicine: pulsus paradoxus. J Postgr Med 2002; 48: 46-9.

12. Nishimura RA. Constrictive pericarditis in the modern era: diagnostic dilemma. Heart 2001; 86: 619-23.
13. Sengupta PP, Krishnamoorthy VK, Abhayaratna WP, et al. Comparison of usefulness of tissue Doppler imaging versus brain natriuretic peptide for differentiation of constrictive pericardial disease from restrictive cardiomyopathy. Am J Cardiol 2008; 102: 357-62.

14. Cimino JJ, Kogan AD. Constrictive pericarditis after cardiac surgery: report of three cases and review of the literature. Am Heart J 1989; 118: 1292-301.

15. Larrieu AJ, Tyers GF, Williams EH, Derrick JR. Recent experience with tuberculous pericarditis. Ann Thorac Surg 1980; 29: 464-8.

16. Hatle LK, Appleton CP, Popp RL. Differentiation of constrictive pericarditis and restrictive cardiomyopathy by Doppler echocardiography. Circulation 1989; 79: 357-70.

17. Nordrehaug JE, Danielsen R, Vik-Mo H. Assessment of the left ventricular diastolic function in constrictive pericarditis by digitised M-mode echocardiography. Ann Clin Res 1988; 20: $164-8$.

18. Kojima S, Yamada N, Goto Y. Diagnosis of constrictive pericarditis by tagged cine magnetic resonance imaging. $\mathrm{N}$ Engl J Med 1999; 341: 373-4.

19. Reinmüller R, Gürgan M, Erdmann E, Kemkes BM, Kreutzer E, Weinhold C. CT and MR evaluation of pericardial constriction: a new diagnostic and therapeutic concept. J Thorac Imaging 1993; 8: 108-21.

20. Zipes D, Libby P, Bonow R, Braunwald E. Braunwald's Heart Disease: A Textbook of Cardiovascular Medicine. 7 ed. Elsevier Saunders, Philadelphia 2005.

21. Cameron J, Oesterle SN, Baldwin JC, Hancock EW. The:etiologic spectrum of constrictive pericarditis. Am Heart J 1987; 113: 354-60.

22. Dalton JC, Pearson RJ, Jr., White PD. Constrictive pericarditis: a review and long-term follow-up of 78 cases. Ann Intern Med 1956; 45: 445-58.

23. Cooley JC, Clagett OT, Kirklin JW. Surgical aspects of chronic constrictive pericarditis; a review of 72 operative cases. Ann Surg 1958; 147: 488-93.

24. Sengupta PP, Eleid MF, Khandheria BK. Constrictive pericarditis. Circ J 2008; 72: 1555-62

25. Schwefer M, Aschenbach R, Heidemann J, Mey C, Lapp $\mathrm{H}$. Constrictive pericarditis, still a diagnostic challenge: comprehensive review of clinical management. Eur J Cardiothor Surg 2009; 36: 502-10.

\section{Constrictive pericarditis with severe heart failure - a case report and review of the literature}

Constricitve pericarditis is an uncommon condition, often of unknown etiology but can be caused by infections, such as tuberculosis, inflammation of the pericardium, radiation therapy or asbestos exposure. Constrictive pericarditis is characterized by fibrosis and often severe calcifications of the pericardial sac which eventually restricts normal diastolic filling of the heart. This consequently leads to a combination of left and right heart failure, often with prominent jugular venous distentsion, liver enlargement, peripheral edema and lethargy. Diagnosis can be difficult and is often delayed. Surgery, involving partial removal of the pericardial sac, usually leads to relief of symptoms. Here we report a case from Landspitali together with a review of the literature.

Einarsson JT, Danielsen R, Indridason OS, Gudbjartsson T.

Constrictive pericarditis with severe heart failure - a case report and review of the literature. Icel J Med 2010; 96: 475-80.

Key words: Constrictive pericarditis, cardiac failure, oedema, echocardiography, cardiac cathederization, pericardectomy. Correspondence: Tómas Guðbjartsson, tomasgud@landspitali.is 